\title{
THE INFLUENCE OF THE UTILIZATION COMPUTER MEDIA AND VISUAL MEDIA TOWARD MATHEMATICS LEARNING OUTCOMES OF STUDENT GRADE VII AT SMP MUHAMMADIYAH 2 KALASAN
}

\author{
Dita Ismiasih ${ }^{\mathrm{a}}$, Suparman $^{\mathrm{b}}$ \\ Program Studi Pendidikan Matematika FKIP UAD \\ Jln. Ringroad Selatan, Tamanan, Banguntapan, Bantul, Yogyakarta \\ adita2493@gmail.com, $\underline{\text { buparman@ pmat.uad.ac.id }}$
}

\begin{abstract}
This research was done because there are many students who are less active, less enthusiastic in the learning process and fewer utilization media that the learning outcomes obtained are less optimal. This research aims to determine the influence of the utilization of computer media and visual media toward mathematics learning outcomes of students' grade VII at SMP Muhammadiyah 2 Kalasan Sleman of even semester in the academic year 2015/2016. This was the control group posttest only. The population in this research were students class VII SMP Muhammadiyah 2 Kalasan district Sleman. Samples were taken using random sampling techniques derived from class VII D as an experimental class and class VII E as the control class. The data collection is done with the test method. A testing instrument using validity and reliability. Data were analyzed using analysis prerequisite tests including normality test with the formula Chi-Kuadrat, homogeneity test by test Bartlett, and hypothesis testing with t-test. Based on calculations by the significant level $\alpha=5 \%$ and the degrees of freedom 54, we concluded that: (1) There are differences in learning outcomes of students using computer media and using visual media. This is indicated by the results of the first test of the hypothesis that $t_{\text {count }}=2,040>t_{\text {table }}=2,005$ (2) learning using computer medial is more effective than learning using visual media. It is shown on the second hypothesis that the test results $t_{\text {count }}=2,040>t_{\text {table }}=1,674$.
\end{abstract}

Keywords: Influence, Media, Mathematics Learning Outcomes

\section{INTRODUCTION}

Technology is a familiar word today. The increasingly rapid development of technology requires various parties to always actively follow developments to meet the needs that are now attached to technology including the world of education. The entry of technology in the world of education is expected to increase the creativity and innovation of teachers in the delivery of learning materials for the sake of improving the quality of education. Education has an important role in everyday life. A good education can create a better generation. Every human being has the right to education. Through education, it is hoped that a quality generation that is intelligent, strong, devoted and able to fulfill their responsibilities will emerge. The function of national education described in Law Number 20 of 2003 concerning the National Education System is: National Education functions to develop abilities and shape national character and civilization, aiming to develop the potential of students to become human beings who believe and devote to God Almighty, have noble character, are healthy, knowledgeable, capable, creative, independent, and become democratic citizens and responsible. In order to improve the quality of education, many ways have been done both by the government and related parties including improving the curriculum, improving teaching materials, optimizing the teaching and learning process, procuring appropriate books, and various other things that are still being pursued.

Nevertheless, in practice learning in schools still encounters many obstacles so that the learning objectives achieved are not in line with expectations. These include math subjects, even though these subjects are in all levels of education, from elementary to tertiary education. Mathematics learning given to students aims to equip students with the ability to think logically, critically, creatively, analytically, and the ability to cooperate. This ability is given to students to have the ability to obtain, manage and utilize information to solve problems in daily life. Mathematics learning is developed to train students to solve problems and communicate ideas through symbols, tables, and other media. Mathematics is a basic science that supports the development of science and technology, therefore mastery of mathematics must be possessed by every student. Mathematics has an object of thought that is abstract in nature so generally, mathematics is still considered difficult by some students. 
According to Van de Henvel-Panhuizen in Sudaryana, Rostina (2014: 24) when children learn mathematics apart from their daily experiences, children will quickly forget and cannot apply mathematics. Based on these opinions, mathematics learning should associate mathematical concepts with experience in daily activities. Learning mathematics requires learning media to be able to associate mathematical concepts with daily activities. According to Mujiono in Sudaryana, Rostina (2014: 25) in the teaching and learning process there are four important components that influence the success of student learning, namely teaching materials, learning atmosphere, media and learning resources, and teachers as subjects of learning. These components are very important in the learning process so that the weakening of one or more components can hinder the achievement of optimal learning goals.

To optimize learning goals, one of them can be used by the media in the teaching and learning process. According to Arsyad (2013: 3) media comes from Latin which literally means middle, intermediary or introduction. In Arabic, the media is an intermediary or delivery message from the sender to the recipient of the message. Media in the teaching and learning process tends to be interpreted as graphical, photographic, or electronic devices to capture, process, and reconstruct visual and verbal information. According to Bovee in Sudaryana (2014: 6), educational media or learning media grow and or develop in line with the development of learning technology. The substance of learning media is 1) the channel form used to channel messages, information or learning material to the recipient of the message or learner 2) various types of components in a learning environment that can stimulate learners to learn 3 ) forms of physical tools that can present messages and stimulate students to can learn and 4) forms of communication that can stimulate learners to learn, both print and audio, visual and audiovisual.

Learning outcomes are indicators of changes that occur in students after experiencing the learning process. Learning outcomes regarding students' ability to solve problems and understand learning material. This is where students' ability to understand learning material can be known. Based on the brief interview of the researcher with mathematics teacher on October 30, 2015, mathematics learning outcomes were still low as indicated by the low average of even semester midterm test scores of class VII SMP Muhammadiyah 2 Kalasan Even Semester Regency 2015/2016 Academic Year can be seen in Table 1.

Table 1. The Value of Even Semester Middle Exams of Class VII Students 2015/2016 Academic Year

\begin{tabular}{|l|l|l|l|l|}
\hline Value & Indonesian & English & Mathematics & Science \\
\hline Average & 75,85 & 40,71 & 47,66 & 56,74 \\
\hline Lowest & 31,43 & 20,00 & 20,00 & 20,00 \\
\hline Highest & 100,00 & 88,57 & 92,50 & 90,00 \\
\hline
\end{tabular}

Source: SMP Muhammadiyah 2 Kalasan

From Table 1 it can be seen that the average value of mathematics subjects all students have not reached the Minimum Completion Criteria (MCC), which is 75 . There are many factors that influence the low learning outcomes, while the learning atmosphere is lacking in motivating students to be active in learning activities. Based on observations made by researchers on November 9, 2015, it was found that most students in the class were less active in learning activities and did not pay attention to the material presented by the teacher. Meanwhile, based on the teacher's information in the interview conducted by the researcher, it was found that students were less enthusiastic about taking mathematics lessons. Students tend to be more interested in stories than listening to math lessons. This was supported by facts in the field at the time of observation that some students were less enthusiastic and actually did other things outside the learning activities. Lack of use of learning media to motivate students to understand learning material. Through interviews, the teacher explained that it is rare to use learning media especially computer media. He argues that the use of computer media takes time because it requires special preparation.

Based on the teacher's information in the interview conducted by the researcher, it was found that the limited media owned by the school also affected learning activities. The use of instructional media can only be done on certain materials to adjust to the learning media available at school. In addition to the factors above, based on observations obtained that learning is still based on teacher activities. This can be seen from various conditions when the learning process takes place. The teacher does a stimulus several times so that students are more active such as giving questions, but this does not get the student's response and in the end, the learning seems to be still based on the teacher.

Based on this background, the compilers were interested in conducting a study on the Effect of Computer Media and Visual Media Usage on Grade VII Mathematics Learning Outcomes of Students of 
SMP Muhammadiyah 2 Kalasan Regency Even Semester 2015/2016 Academic Year. Based on the background of the problem, the problem can be formulated to be examined as follows:

1. Are the mathematics learning outcomes of seventh-graders in Even Semester SMP Muhammadiyah 2 Kalasan Sleman Semester District 2015/2016 Academic Year that use computer media different from those using visual media?

2. Are the mathematics learning outcomes of seventh-grade students of Even Semester SMP Muhammadiyah 2 Kalasan, Sleman Even Semester 2015/2016 Academic Year that use computer media more effective than those using visual media?

In connection with the formulation of the problem described, the objectives to be achieved in this study are:

1. Knowing the difference in learning outcomes of mathematics that uses computer media and the results of learning mathematics using visual media.

2. Knowing which mathematics learning outcomes are more effective between computer media or visual media.

\section{METHODS}

This type of research is experimental research. According to Suparman (2015: 1), experimental research is a study conducted by learning something held. In other words, in the experimental research, there was treatment from the researcher and measured the impact. This research was conducted intentionally in class or at school to try to raise the variables studied in mathematics learning. The research design in this study used two classes namely the experimental class and the control class. In the experimental class, learning is done using computer media, while controls use visual media. In this study, the posttest was done equally for the experimental class and for the control class. The design of this study is illustrated in Table 2 .

Table 2 Post Only Control Groups with Random Subjects

\begin{tabular}{|l|l|l|l|}
\hline & Group & Treatment & Postes \\
\hline$(\mathrm{R})$ & Experiment & $\mathrm{X}_{1}$ & $\mathrm{Y}_{1}$ \\
\hline$(\mathrm{R})$ & Control & $\mathrm{X}_{2}$ & $\mathrm{Y}_{2}$ \\
\hline
\end{tabular}

(Sukardi 2012:185)

Information:

Experiment : Classes that use computer media

Control : Classes that use visual media

$\mathrm{X}_{1} \quad$ : Treat using computer media

$\mathrm{X}_{2} \quad$ : Treatment using visual media

$\mathrm{Y}_{1} \quad$ : Learning result test after treatment using computer media

$\mathrm{Y}_{2} \quad$ : Test of learning outcomes after treatment using visual media

This research was conducted at SMP Muhammadiyah 2 Kalasan, Sleman Regency. The time used for data collection in this study is the even semester 2015/2016 academic year. Grade VII students of SMP Muhammadiyah 2 Kalasan Sleman Regency 2015/2016 academic year consisted of 5 classes, namely class VII A, VII B, VII C, VII D, and VII E. Samples were taken 2 classes using random sampling technique, obtained class VII D as the experimental class and class VII E as the control class. Data collection techniques used are observation methods and test methods. Observations used in the form of the results of observation activities of mathematics learning activities of class VII students of SMP Muhammadiyah 2 Kalasan to find out the conditions during learning. While the tests in the form of learning outcomes tests (posttest) were given after being treated with computer media and visual media.

The instrument used was a learning outcome test on the subject of Quadrilateral in the form of a test of mathematics learning outcomes. Before being tested in the experimental class, so that the learning outcome test questions are arranged not to deviate from the material to be taught, then a grid is made, test questions, and review the items of the test results of mathematics learning. After the test instruments were arranged, then tested on the instrument trial class, namely class VII B. After the test questions were tested, the test items were analyzed by validity test using the product-moment correlation formula, the discriminating power using the discrimination index formula, and the reliability test using the formula Kuder Richardson-20 (KR-20). The analysis prerequisite test used the normal test with the Chi-Square test and the homogeneity test with the Bartlet test. Hypothesis testing is used by both parties and one party. 


\section{RESULTS AND DISCUSSION}

Based on the research that has been carried out obtained data in the form of initial abilities and student learning outcomes.

\section{Early Ability}

The value of the initial ability was obtained from the results of Even Semester Middle Examination grades VII D and class VII E SMP Muhammadiyah 2 Kalasan Sleman Regency and obtained the value of the initial mathematical abilities as produced in Table 3.

Table 3. Summary of Description of Initial Capability Value

\begin{tabular}{|l|c|c|}
\hline \multicolumn{1}{|c|}{ Class } & $\begin{array}{c}\text { Experiment } \\
\text { (VII D) }\end{array}$ & $\begin{array}{c}\text { Control } \\
\text { (VII E) }\end{array}$ \\
\hline The highest score & 75 & 75 \\
\hline Nlai is the lowest & 22.5 & 28 \\
\hline Average & 44.08 & 46.25 \\
\hline Standard Deviation & 11.81 & 10.6 \\
\hline Variance & 139.51 & 112.3 \\
\hline Lots of data & 28 & 28 \\
\hline
\end{tabular}

a. Normal Ability Test

The normality test is used to determine whether or not the normal distribution of initial ability data for each experimental and control class. The researcher calculates the normality test twice, namely the normality test for the experimental class and the normality test for the control class. The summary results of the normal ability normality test can be seen in Table 4 .

Table 4. Summary of Initial Ability Normality Test Results

\begin{tabular}{lcc}
\hline Class & $\chi^{2}{ }_{\text {count }}$ & $\boldsymbol{\chi}_{\text {table }}^{\mathbf{2}}$ \\
\hline Experiment & 5.148 & 5.9915 \\
Control & 1.202 & 5.9915 \\
\hline
\end{tabular}

From the normality test at a significant level of $5 \%$ and the degree of freedom $=3$, it can be seen that $\chi_{\text {count }}^{2}=5.148$ and $\chi_{\text {table }}^{2}=5.9915$, so that $\chi_{\text {count }}^{2}<\chi_{\text {table }}^{2}$ which means that the experimental class has initial ability data that are normally distributed. While the normality test at a significant level of $5 \%$ and the degree of freedom $=3$, it can be seen that $\chi_{\text {count }}^{2}=1.202$ and $\chi_{\text {table }}^{2}=5.9915$, so that $\chi_{\text {count }}^{2}<\chi_{\text {table }}^{2}$ which means that the dick class has initial ability data that are normally distributed.

b. Homogeneity Test of Early Capabilities

The homogeneity test on the data is intended to investigate whether the two samples have the same variance or not. The test used to test the similarity of the sample variance is the Bartlet test because the average and population variance is unknown and consists of two samples of the same size. The summary results of the initial homogeneity test can be seen in Table 5 .

Table 5. Summary of Initial Ability Homogeneity Test Results

\begin{tabular}{cc}
\hline$\chi_{\text {count }}^{2}$ & $\chi_{\text {table }}^{2}$ \\
\hline 2.332 & 3,842 \\
\hline
\end{tabular}

From the homogeneity test at a significant level of 5\% and the degree of freedom $=1$, it can be seen that $\chi_{\text {count }}^{2}=2.332$ dan $\chi_{\text {table }}^{2}=3,842$, so that $\chi_{\text {count }}^{2}<\chi_{\text {table }}^{2}$ which means both classes have the same variance (homogeneous).

c. Test the Initial Ability Hypothesis

The summary of the results of the hypothesis test the similarity of the initial capabilities can be seen in Table 6 .

Table 6. Summary of Two-party Hypothesis Test Results Initial Capabilities

\begin{tabular}{cc}
\hline $\boldsymbol{t}_{\text {count }}$ & $\boldsymbol{t}_{\text {table }}$ \\
\hline 0.6569 & 1.674 \\
\hline
\end{tabular}

From the hypothesis test similarity at a significant level of $5 \%$ and the degree of freedom $=54$, it can be seen that $t_{\text {count }}=0.6569$ and $t_{\text {table }}=1.674$, so that $t_{\text {count }}<t_{\text {table }}$ which means 
there is no difference between the initial ability of students of Muhammadiyah Middle School 2 Kalasan Sleman Regency VII grade even semester 2015/2016 academic year.

\section{Mathematics Learning Results}

Descriptions of data on student mathematics learning outcomes after the experiment are presented in Table 7.

Table 7. Summary of Description of Value of Mathematics Learning Outcomes

\begin{tabular}{|l|c|c|}
\hline Class & $\begin{array}{l}\text { Experiment } \\
\text { (VII D) }\end{array}$ & $\begin{array}{l}\text { Control } \\
\text { (VII E) }\end{array}$ \\
\hline The highest score & 80 & 86.67 \\
\hline Lowest value & 40 & 40 \\
\hline Average & 62,381 & 56,667 \\
\hline Standard Deviation & 9,778 & 11,403 \\
\hline Variance & 95,602 & 130,03 \\
\hline Lots of data & 28 & 28 \\
\hline
\end{tabular}

\section{a. Normality Test of Learning Outcomes}

The normality test is used to determine whether or not normal data distribution of learning outcomes for each experimental and control class. The researcher calculates the normality test twice, namely the normality test for the experimental class and the normality test for the control class. The calculation results show that the experimental class and the control class meet the normality requirements. The summary test for normality of learning outcomes can be seen in Table 8.

Table 8. Summary of Normality Test Learning outcomes

\begin{tabular}{ccc}
\hline Class & $\boldsymbol{\chi}_{\text {count }}$ & $\boldsymbol{\chi}_{\text {table }}$ \\
\hline Experiment & 0,054 & 7,8147 \\
Control & 5,506 & 5,9915 \\
\hline
\end{tabular}

From the normality test at a significant level of $5 \%$ and the degree of freedom $=3$, it can be seen that $\chi_{\text {count }}^{2}=0,054$ and $\chi_{\text {table }}^{2}=7,8147$, so that $\chi_{\text {count }}^{2}<\chi_{\text {table }}^{2}$ which means that the experimental class has learning outcomes data that are normally distributed. While the normality test at a significant level of 5\% and degrees of freedom $=2$, it can be seen that $\chi_{\text {count }}^{2}=5,506$ and $\chi_{\text {table }}^{2}=5,9915$, so that $\chi_{\text {count }}^{2}<\chi^{2}$ table which means the dick class has data on learning outcomes that are normally distributed.

\section{b. Homogeneity Test of Learning Outcomes}

The homogeneity test on learning outcomes data is intended to investigate whether the two samples have the same variance or not. The test used to test the similarity of the sample variance is the Bartlet test because the average and population variance is unknown and consists of two samples of the same size. The summary test for homogeneity of learning outcomes can be seen in Table 9.

Table 9. Homogeneity Test Summary Learning outcomes

\begin{tabular}{cc}
\hline$\chi_{\text {count }}^{2}$ & $\chi_{\text {table }}^{2}$ \\
\hline 0,4197 & 3,8415 \\
\hline
\end{tabular}

From the homogeneity test at a significant level of $5 \%$ and the degree of freedom $=1$, it can be seen that $\chi_{\text {count }}^{2}=0,4197$ and $\chi_{\text {table }}^{2}=3,8415$, so that $\chi_{\text {count }}^{2}<\chi_{\text {table }}^{2}$ which means both classes have the same variance (homogeneous).

c. Test the Two Parties Hypothesis

$\mathrm{H}_{0}: \mu_{1}=\mu_{2}$

$\mathrm{H}_{1}: \mu_{1} \neq \mu_{2}$

$H_{0}$ : There was no difference between the learning outcomes of mathematics using computer media and those using visual media in class VII students in the even semester of SMP Muhammadiyah 2 Kalasan 2015/2016 academic year. 
$H_{1}$ : There is a difference between the learning outcomes of mathematics using computer media and those using visual media in class VII students in the even semester of SMP Muhammadiyah 2 Kalasan 2015/2016 academic year.

The summary of the results of the first hypothesis test can be seen in Table 10.

Table 10. Summary of Test of Two-Part Hypothesis

\begin{tabular}{cc}
\hline $\boldsymbol{t}_{\text {count }}$ & $\boldsymbol{t}_{\text {table }}$ \\
\hline $\mathbf{2 , 0 4 0}$ & 2,005 \\
\hline
\end{tabular}

From the two-party hypothesis test at a significant level of $5 \%$ and the degree of freedom $=54$, it can be seen that $t_{\text {count }}=2,040$ and $t_{\text {table }}=2,005$, so that $t_{\text {count }}>t_{\text {table }}$ which means there is a difference between the mathematics learning outcomes of students who use computer media and those who use visual media in class VII SMP Muhammadiyah 2 Kalasan Sleman Regency even semester 2015/2016 academic year.

\section{d. Test of One Party Hypothesis}

$\mathrm{H}_{0}: \mu_{1}=\mu_{2}$

$\mathrm{H}_{1}: \mu_{1}>\mu_{2}$

With

$\mathrm{H}_{0} \quad$ : Computer media and visual media have the same effect on the mathematics learning outcomes of class VII SMP Muhammadiyah 2 Kalasan Sleman Even Semester Year 2015/2016 Academic Year.

$\mathrm{H}_{1} \quad$ : The use of computer media is more effective than visual media on the mathematics learning outcomes of class VII students of SMP Muhammadiyah 2 Kalasan Sleman Even Semester Year 2015/2016 Academic Year.

After it is known that there is no difference between the mathematics learning outcomes of the experimental class students and the control class, then one party hypothesis testing is carried out, as can be seen in Table 11 .

Table 11. Summary of the One-Party Hypothesis Test

\begin{tabular}{cc}
$\boldsymbol{t}_{\text {count }}$ & $\boldsymbol{t}_{\text {table }}$ \\
\hline $\mathbf{2 , 0 4 0}$ & 1,674 \\
\hline
\end{tabular}

From the second hypothesis test at a significant level of 5\% and the degree of freedom $=54$, it can be seen that $t_{\text {count }}=2,040$ and $t_{\text {table }}=1,674$, so that $t_{\text {count }}>t_{\text {table }}$ which means that computer media is more effective than visual media on the mathematics learning outcomes of class VII students of SMP Muhammadiyah 2 Kalasan Sleman Regency even semester 2015/2016 academic year.

\section{CONCLUSION}

Based on the analysis of the experimental data and the discussion, it can be concluded as follows:

1. There is a difference between the learning outcomes of mathematics using computer media and those who use visual media in grade VII students in the even semester of SMP Muhammadiyah 2 Kalasan even semester 2015/2016 academic year. This is indicated by the results of the first hypothesis test wherewith a significant level of $5 \%$ and the degree of freedom 54, the values obtained $t_{\text {count }}=2,040$ and $t_{\text {table }}=2,005$, means $t_{\text {count }}>t_{\text {table }}$, so that $H_{0}$ is rejected, $H_{1}$ is accepted.

2. Mathematics learning outcomes of Grade VII students of SMP Muhammadiyah 2 Kalasan Sleman Regency even semester 2015/2016 academic year that use computer media are more effective than those using visual media. This is indicated by the results of the second hypothesis test wherewith a significant level of $5 \%$ and the degree of freedom 54, the values obtained $t_{\text {count }}=2,040$ and $t_{\text {table }}$ $=1,674$, means $t_{\text {count }}>t_{\text {table }}$, so that $H_{0}$ is rejected, $H_{1}$ is accepted.

\section{REFERENCES}

Arsyad, Azhar dan Asfah Rahman (ed). 2013. Media Pembelajaran. Jakarta: RajaGrafindo Persada.

Sudaryana, Rostina. 2014. Media dan Alat Peraga dalam Pembelajaran Matematika. Bandung: Alfa Beta.

Sukardi. 2012. Metodologi Penelitian Pendidikani. Jakarta: Bumi Aksara.

Suparman. 2015. Metode Penelitian Pendidikan. Yogyakarta: MIPA UAD Press.

Undang-Undang Republik Indonesia No.20 Tahun 2003 Bab 1 Pasal 1 Pendidikan Nasional. 